\title{
Agama, Etnisitas dan Perdamaian di Pulau Enggano Provinsi Bengkulu
}

\section{Intan Permata Sari ${ }^{*}$}

1 IAIN Bengkulu, Indonesia; e-mail: intanpermatasari1112@gmail.com

* Correspondence

Received: 2020-10-18; Accepted: 2020-11-12; Published: 2020-12-31

\begin{abstract}
This article explores the diversity of ethnicities and religions in the Engganese society, which has become color in their life dynamics - local wisdom based on customary rules succeeded in uniting differences into peace. Ethnic and religious differences, which have been considered dividing the nation, did not occur in the Enggano community. This study uses a qualitative method by interviewing several vital informants who are religious or traditional leaders. The purpose of this study is to show that ethnic and religious differences can create harmony and peace in society. The results of this study are that the Enggano community is an open society that easily accepts the presence of newcomers; then that migrants get the same rights and obligations as indigenous people; also that migrants are required to give up their cultural identity when entering Enggano; that religion is a new value in the Enggano community which is not regulated by custom; and that adat has an important role in shaping the behavior of the Engganese people. These factors are the keys to peace in a multiethnic and multi-religious society.
\end{abstract}

Keywords: Enggano; ethnicity; local culture; peace; religion

Abstrak: Artikel ini menelusuri keragamaan etnis dan agama dalam masyarakat Enggano yang menjadi warna dalam dinamika kehidupan mereka. Kearifan lokal yang didasari oleh aturan-aturan adat berhasil mempersatukan perbedaan menjadi sebuah perdamaian. Perbedaan etnis dan agama yang selama ini dianggap sebagai pemecahbelah bangsa ternyata tidak terjadi dalam kasus masyarakat Enggano. Penelitian ini menggunakan metode kualitatif dengan mewawancarai beberapa informan kunci yang merupakan tokoh agama ataupun tokoh adat. Tujuan dari penelitian ini adalah memperlihatkan bahwa perbedaan etnis dan agama mampu membuat sebuah harmoni dan damai dalam masyarakat. Hasil dari penelitian ini adalah bahwa masyarakat Enggano adalah masyarakat terbuka yang dengan mudah menerima kehadiran pendatang; kemudian bahwa pendatang mendapatkan hak dan kewajiban yang sama dengan masyarakat asli; juga bahwa pendatang diharuskan melepaskan identitas kultural mereka ketika memasuki Enggano; bahwa agama merupakan nilai baru dalam masyarakat Enggano yang tidak diatur oleh adat; dan bahwa adat memiliki peranan penting dalam membentuk perilaku masyarakat Enggano. Faktor-faktor inilah yang menjadi kunci perdamaian dalam masyarakat yang multi-etnis dan multi-religi.

Kata Kunci: agama; Enggano; etnis; kearifan lokal; perdamaian

\section{Pendahuluan}

Identitas etnis terbentuk seiring dengan identitas agama yang diyakini. Identitas agama melekat dan mempengaruhi nilai-nilai yang berlaku pada etnis tersebut sehingga menjadi penciri suatu etnis. Seperti etnis Minangkabau identik dengan agama Islam, etnis Bali yang identik dengan agama Hindu, serta etnis Dayak yang identik dengan agama Kristen. Pengkotak-kotakan identitas etnis dapat menjadi pemecahbelah bangsa dan dapat memicu konflik di tengah masyarakat terutama ketika konflik tersebut dikaitkan dengan simbol-simbol agama tertentu. Kasus konflik Ambon misalnya sampai membuat batas geografis antara masyarakat beragama Islam dan Kristen (Dandirwalu \& Rehy, 2020; Lestari, 2020; Lestari \& Parihala, 2020; Rozi, 2016). Pada kasus yang lain, simbol-simbol agama selalu 
dibawa dalam perebutan kekuasaan seperti pemilihan kepala daerah atau kepala negara (Akbar, 2005; Rachmadi, 2006). Meskipun begitu kita masih bisa belajar dari masyarakat Enggano yang multi-cultural dan multi-religion di mana ketaatan terhadap kearifan lokal menjadi kunci dalam menjaga harmoni dalam masyarakat.

Sejauh ini studi mengenai relasi antara etnisitas, agama, dan perdamaian jarang diperhatikan. Penelitian-penelitian terdahulu seringkali hanya memandang dalam dua aspek saja dan seringkali menghubungkan perbedaan etnis dan budaya sebagai akar konflik. Seperti agama dan perdamaian (Abdullah, 2018; Hidayat, 2017; Irawan, 2014); nilai-nilai kultural dalam menjaga perdamaian (Ernas, 2015; Feriyanto, 2018; Nurdin, 2013) konflik dalam masyarakat yang multicultural dan multireligion (Alhamid, 2014; Hamid, 2013; Lestari \& Parihala, 2020; Lindawaty, 2011); resolusi konflik (Ardiansyah, 2010); serta harmoni dalam kehidupan bermasyarakat (Ayubi, 2016; Ernas et al., 2014). Kajian-kajian terdahulu seringkali mendudukkan perbedaan agama dan identitas etnis sebagai sumber dari konflik di berbagai daerah sedangkan kajian yang lain berhasil menggunakan budaya lokal sebagai kekuatan menjadi harmoni di tengah keragaman suku dan agama.

\section{Metode Penelitian}

Tulisan ini didasari oleh argumen bahwa perbedaan etnis dan agama tidak selalu menjadi pemicu konflik dalam masyarakat. Perbedaan etnis dan agama bisa dilihat dengan cara berbeda sebagai warnawarni dalam masyarakat. Perdamaian yang terjadi pada masyarakat Enggano didasari oleh kepatuhan mereka kepada nilai-nilai adat dan kearifan lokal yang dibangun oleh para leluhur, kelapangan hati penduduk asli dalam menerima pendatang dan memberikan mereka hak dan kesempatan yang sama, serta kerendahan hati para pendatang untuk melepaskan identitas kultural mereka dan kemudian beradaptasi dengan nilai-nilai baru. Faktor-faktor tersebut merupakan kunci perdamaian masyarakat Enggano yang terus diyakini, dipelihara, dan dipraktikkan.

Penelitian ini menggunakan jenis penelitian deskriptif kualitatif, yaitu penelitian yang memaparkan serta mengumpulkan informasi secara rinci sehingga dapat menggambarkan harmoni dalam masyarakat multi-cultural di Enggano. Penelitian ini dilakukan dengan studi lapangan selama dua minggu di Enggano. Data yang diperoleh sebagaimana adanya yang terjadi di lapangan, yang dialami, dirasakan dan dipikirkan oleh sumber data bukan dari yang dipikirkan oleh peneliti (van Manen, 2017). Untuk mencari data peneliti menggunakan metode wawancara. Wawancara dilakukan dengan sejumlah informan kunci (Chadwick, 2017). Informan yang dimaksud adalah ketua suku, tokoh masyarakat dan tokoh agama.

Studi ini ingin memperlihatkan bahwa etnisitas yang membawa identitas agama nyatanya mampu membawa perdamaian di tengah masyarakat Enggano yang multikultural. Hal ini dikarenakan di satu sisi adat mampu menjadi perekat dan di sisi lain sebagai pembatas terhadap perbedaan kultural dan agama di Pulau Enggano. Selain itu, tulisan ini juga ingin memperlihatkan faktor-faktor yang menyebabkan masyarakat Enggano mampu hidup rukun dan damai di tengah keragaman etnis dan agama serta keterbatasan-keterbatasan mereka sebagai masyarakat pulau terluar yang minim akses dan fasilitas negara.

\section{Hasil Penelitian}

\section{Keragaman Etnis dan Identitas Agama di Pulau Enggano}

Enggano merupakan sebuah pulau terluar di Provinsi Bengkulu yang berukuran kurang lebih 40 $\mathrm{km} \times 17 \mathrm{~km}$ (Sari, 2017). Lokasi pulau ini cukup terpencil karena akses ke wilayah ini sangat terbatas. Untuk mencapai Enggano dibutuhkan waktu kurang lebih 12 jam perjalanan laut menggunakan kapal Feri atau kapal Perintis. Enggano memiliki dua buah pelabuhan yaitu Pelabuhan Feri yang terletak di Desa Kahyapu dan Pelabuhan Kapal Perintis yang terletak di Desa Malakoni. Pulau Enggano terdiri dari enam desa, yaitu Desa Kahyapu, Kaana, Malakoni, Apoho, Meok, dan Banjarsari (Sari, 2018). Pusat kecamatan desa Enggano berada di Desa Apoho, yang terletak di tengah-tengah pulau. Desa Apoho dan Desa Meok merupakan desa yang dihuni oleh mayoritas suku asli Enggano yang mayoritas 
beragama Kristen sedangkan keempat desa lainnya dihuni oleh para pendatang yang mayoritas beragama Islam.

Sebagai bagian dari kategori masyarakat 3T (terdepan, terluar, tertinggal) fasilitas di pulau ini masih sangat terbatas. Tidak ada transportasi lokal yang bisa diakses ketika kita sampai di Pulau Enggano. Pendatang atau turis yang datang ke Enggano harus membawa kendaraan roda dua atau meminta penduduk lokal untuk menjemput mereka di Pelabuhan. Dua Pelabuhan di Enggano masih tergolong kecil. Pelabuhan Feri, terletak di Desa Kahyapu, hanya digunakan kapal Feri untuk berlabuh. Kapal Feri hanya mampu menampung kurang lebih 2-4 kendaraan roda empat (biasanya berisi truktruk pengantar pisang) dan kurang lebih 10 kendaraan roda dua. Pelabuhan Perintis, terletak di Desa Malakoni, merupakan tempat berlabuh kapal perintis. Kapal ini tidak bisa membawa kendaraan roda empat dan hanya diperbolehkan membawa kendaraan roda dua dengan syarat tidak boleh ada bensin di dalamnya.

Masyarakat Enggano terdiri dari lima suku asli yaitu Kauno, Kaitora, Kaarubi, Kaaruba, dan Kaahoao serta satu suku pendatang yang bernama Kaamay (Sari, 2017, 2018). Sebenarnya Enggano memiliki jumlah suku yang lebih banyak tetapi telah punah akibat perang saudara yang terus-menerus dan tersisalah lima suku ini. Masyarakat Enggano tidak mengakui etnis lain selain suku asli dan suku Kaamay sehingga identitas kultural pendatang yang melekat di diri mereka harus dilepaskan dan bersatu menjadi bagian dari masyarakat Enggano. Oleh karena itu ketika kita memasuki Pulau Enggano, kita tidak akan menemukan bahasa lain yang digunakan sehari-hari selain Bahasa Enggano dan Bahasa Indonesia. Kita juga tidak akan menemukan tradisi etnis lain yang dilestarikan dan dipraktikkan di Pulau Enggano.

Suku Kaamay identik dengan agama Islam. Jumlah mereka yang melebihi jumlah penduduk asli Enggano telah menjadikan Islam sebagai agama mayoritas di Enggano meskipun agama pertama orang Enggano asli Enggano adalah Kristen. Di Enggano, pemetakan lokasi tempat tinggal ternyata juga dipengaruhi oleh agama. Masyarakat yang beragama Kristen mayoritas tinggal di Desa Apoho dan Desa Meok sedangkan penganut agama Islam tinggal di empat desa lainnya. Jumlah penganut agama Islam di Enggano berjumlah 2887 orang dengan 11 Mesjid dan 8 Mushola, sedangkan Kristen sebanyak 840 orang dengan 8 Gereja (Data KUA 2018). Meskipun begitu tidak pernah ada konflik agama ataupun bentuk-bentuk protes dari penduduk asli Enggano ketika identitas keagamaan di wilayah mereka telah berganti dengan identitas agama para pendatang.

\section{Masuknya Pendatang ke Enggano}

Portugis adalah bangsa pertama yang diyakini pertama kali berinteraksi dan menemukan Pulau Enggano. Laporan pertama mengenai pulau Enggano berdasarkan catatan Cornelis de Houtman yang mengunjungi pulau ini tanggal 5 juni 1596. Tidak diketahui dari mana de Houtman mengetahui nama pulau ini, yang dalam bahasa Portugis, Engano, berarti "kecewa". Dalam cerita masyarakat Enggano, mereka juga mengakui bahwa Portugis telah datang ke wilayah mereka. Berabad-abad lamanya, Enggano adalah wilayah yang tidak tersentuh wilayah luar sampai akhirnya tahun 1862 orang Portugis datang dan mengajari mereka cara memasak dengan alat masak dan bercocok tanam dan mengajarkan mereka untuk hidup menetap (Ekorusyono, 2015). Orang-orang Portugis juga mengajarkan mereka agama baru (Kristen) tetapi mereka tidak tertarik dan masih mempertahankan kepercayaan kepada nenek moyang.

Setelah bangsa Portugis masuk, Enggano dikuasai oleh Inggris karena wilayah Bengkulu pada waktu itu merupakan jajahan Inggris. Seperti catatan yang ditulis Modigliani bahwa tanggal 2 November 1618, 28 kapal dari Inggris tiba di Enggano. Marsden dalam history of Sumatra mengatakan tahun 1771 Charles Miller dikirim ke Enggano atas perintah Gubenur Wyatt dan Dewan Fort Marlborough (Benculen) untuk mengekplorasi produk-produk pulau itu. Setelah Inggris tidak lagi menguasai Bengkulu, maka kekuasaan atas Enggano menjadi milik Belanda (Modigliani, 1984).

Meskipun begitu, Belanda adalah bangsa yang paling berjasa dengan masyarakat Enggano. Bangsa Belanda pernah menyelamatkan masyarakat Enggano dari penyakit kusta. Pada waktu itu Raja Herman meminta bantuan Belanda dengan menaikkan bendera Belanda di Enggano. Kapal Belanda 
melihat ada bendera mereka kemudian mendekat dan sekitar 10 orang turun ke Enggano dan bertanya ada apa. Raja Herman meminta bantuan mereka karena masyarakat Enggano sedang mengalami sakit kudis, kusta. Sudah banyak masyarakat yang terinfeksi di rumah-rumah dan tidak dapat lagi berjalan. Pasukan-pasukan Belanda ini kemudian kembali ke kapal dan mengambil obat (penisilin). Belanda kemudian meminta masyarakat Enggano untuk berkumpul di Meok untuk pengobatan. Hari pertama yang mendapatkan pengobatan adalah masyarakat Meok dan Malakoni (dulu Apoho masuk dalam wilayah Malakoni). Besoknya Banjar, Kahyapu dengan menggunakan kapal. Setelah diberi pengobatan oleh Belanda semua masyarakat Enggano sembuh. Akibat penyakit ini pula lah posisi tempat tinggal masyarakat Enggano menjadi berubah karena untuk mengobati semua masyarakat yang sakit orang Enggano harus berada di pesisir pantai agar mudah ditemui dan diobati. Sejak saat itu pelan-pelan mereka berpindah dari dalam hutan ke daerah pesisir pantai. Pola pemukiman ini bertahan sampai sekarang di pesisir pantai bagian timur (Kaarubi, 2007).

Selain itu, Jepang juga pernah menguasai Enggano. Jepang masuk ke Enggano tahun 1942 dan meninggalkan Enggano tahun 1945. Pada waktu meninggalkan Enggano, senjata-senjata Jepang seperti bom dan Meriam di buang di tengah laut. Orang-orang Enggano tidak diperbolehkan melihat kepergian Jepang. Semua orang kecuali anak-anak dimasukan ke dalam lubang-lubang yang sebelumnya sudah dipersiapkan. Sepeninggalan Jepang, masyarakat Enggano berpesta pora selama bertahun-tahun. Mereka tidak bekerja hanya makan dan minum dari dua gudang makanan yang ditinggalkan Jepang di Pulau Sebalik dan Desa Apoho. Semua bahan makanan seperti daging, beras, kornet, dan sebagainya menjadi sumber makanan masyarakat Enggano pada saat itu. Setelah semua makanan itu habis masyarakat Enggano mengalami masa paceklik. Seperti yang dikatakan oleh informan: "Begitu Jepang kalah dibawa semua, makanan bergudang-gudang ditinggal, pokoknya makanan pokok itu ditinggal semua, babi ditinggal, sapi ditinggal, itulah orang Enggano dahulu istilahnya berfoya-foya beberapa tahun, nggak pernah kerja karena makanan banyak, kabarnya kalau menurut cerita ibu Mertua itu 4 tahun mereka nggak pernah kerja menghabiskan makanan itu."

Pasca kemerdekaan Indonesia, banyak orang-orang dari luar Enggano datang dan menetap di pulau ini terutama ketika pemerintah Orde Baru menerapkan sistem transmigrasi seperti orang-orang Jawa yang masih menetap sampai saat ini. Di Desa Malakoni masih bisa kita temukan wilayah transmigrasi yang ternyata tidak hanya diisi oleh transmigran tetapi juga ada masyarakat suku asli Enggano yang tinggal di sana. Para transmigran ini diberikan tanah oleh pemerintah dan dibantu untuk pembangunan tempat tinggalnya. Akan tetapi saat ini karena jumlah tanah tidak sebanyak dulu, masyarakat Enggano melalui ketua-ketua sukunya mulai menolak program transmigrasi pemerintah yang jumlahnya puluhan sampai ratusan orang ke Enggano. Mereka masih menerima orang-orang yang bermigrasi secara sukarela demi menyambung hidup di tanah Enggano.

Suku-suku pendatang mulai banyak masuk ke Enggano pada tahun 1960an. Pada waktu itu jumlah suku asli di Enggano hanyalah sekitar 400 orang. Jumlah penduduk ini dibagi dalam tiga desa, yaitu di Dimeo (115 orang), Ka'ana (95 orang), dan Malakoni (190 orang) (Jaspan, 2018). Jumlah ini menyusut tajam dari seratus tahun yang lalu di mana jumlah masyarakat Enggano berjumlah 6420 orang. Hal ini dikatakan Helfrich karena adanya penyakit kolera, penyakit kelamin dan aborsi sehingga dalam 18 tahun turun sekitar 84\% menjadi 914 orang saja (Jaspan, 2018; Sari, 2018). Penurunan jumlah penduduk yang signifikan dikarenakan perang antar suku dan juga penyakit kusta yang menyerang masyarakat Enggano. Penyakit ini kemudian sembuh setelah Belanda memberikan penisilin kepada masyarakat Enggano dan mengasingkan penduduk yang terkena kusta ke pulau kecil di dekat Enggano yang bernama Pulau Bangkai (Sari, 2018).

Dari tabel 1 terlihat bahwa pada pertengahan abad ke-19 jumlah penduduk Enggano tercatat sebanyak 6420. Delapan belas tahun kemudian terjadi penurunan yang sangat signifikan sekitar kurang lebih $85 \%$ (tersisa hanya $15 \%$ saja). Dari data tersebut kita juga melihat bahwa jumlah penduduk asli Enggano terus menurun, begitu juga dengan jumlahnya meskipun pendatang sudah mulai masuk ke Enggano. Puncaknya terjadi pada tahun 1928 yang menyisakan hanya sebanyak 162 penduduk asli, di tahun ini pula lah jumlah pendatang lebih banyak daripada penduduk asli. Dari data juga terlihat pada tahun 1963 masuk pendatang dengan jumlah yang sangat besar (7x dari populasi masyarakat asli 
Enggano). Hal ini karena program pemerintah untuk melakukan tuna karya pembukaan lahan, pembuatan irigasi bagi lahan kering, ekspansi penduduk, dan fasilitas kesehatan (Jaspan, 2018).

Tabel 1 Populasi Masyarakat Enggano dari tahun 1866-1963 (Jaspan, 2018)

\begin{tabular}{cccc}
\hline Year & Engganese & Non-Engganese & Total \\
\hline $\mathbf{1 8 6 6}$ & - & - & 6420 \\
\hline $\mathbf{1 8 8 4}$ & 870 & 44 & 914 \\
\hline $\mathbf{1 9 0 0}$ & 543 & - & - \\
\hline $\mathbf{1 9 1 4}$ & 291 & 166 & 457 \\
\hline $\mathbf{1 9 2 8}$ & 162 & 276 & 438 \\
\hline $\mathbf{1 9 6 1}$ & 400 & 290 & 690 \\
\hline $\mathbf{1 9 6 3}$ & 400 & 2800 & 3200 \\
\hline
\end{tabular}

\section{Masuknya Agama ke Enggano}

Tahun 1902 agama Kristen masuk ke Enggano dibawa oleh misonaris Agust Lett yang diutus oleh R.M.G (Rheinche Mission Geselschaft) bersama guru Kristian Lumban Tobing. Setelah enam bulan menyebarkan agama Kristen ada empat orang penduduk asli Enggano yang masuk Kristen yaitu Ahowadi Kaarubi Kapakuoda (Johannes), Kaparobi Kaitora (Manasye), Painaijo Kaahawao Kakorea (Paulus), dan Kaawao Kapunija Ehijobu (Daniel) (Hutapea \& Simangunsong, 1994). Keempat orang inilah yang pertama kali memeluk agama. Lama kelamaan, agama Kristen mulai menyebar di Enggano dan menjadikan Kristen sebagai agama mayoritas sampai akhirnya saat ini bergeser menjadi minoritas setelah banyak pendatang Islam masuk ke Enggano. Data dari Kantor Urusan Agama tahun 2018, jumlah penganut Islam sebanyak 2887 jiwa $(77,46 \%)$ dan Kristen sebanyak 840 jiwa (22,54\%).

Agama Islam pertama kali diperkenalkan tahun 1906 oleh seorang muslim dari Banten bernama Pak Sidin. Beliau menetap di Enggano, kemudian menikah dengan orang asli Enggano, dan menetap di Desa Kaana. Beliau, anak-anaknya, serta tokoh-tokoh Islam dari Minangkabaulah yang menyebarkan agama Islam di Pulau Enggano. Saat ini Islam menjadi agama mayoritas karena ada banyak pendatang muslim yang menjadi penduduk Enggano dan menikah dengan penduduk asli sehingga banyak penduduk asli yang berpindah agama menjadi Islam. Seperti yang dikatakan oleh informan: "Orang-orang Banten datang ke Enggano untuk mengembangkan agama. Islam ini mulai berkembang sekitar tahun 30-an, sudah itu ditambah orang dari kedatangan orang-orang dari Sumatera Barat. Masjid yang pertama itu ada di Pulau Dua, yang pertama didirikan oleh orang-orang dari Banten setelah Belanda pergi dari Enggano mereka pindah ke Kahyapu, kebanyakan orang Kahyapu itu asli orang Banten."

Islam pertama kali diperkenalkan di Pulau Dua (pulau kecil di seberang Enggano). Dahulu Pulau Dua merupakan pusat kehidupan di Enggano. Ada banyak toko dan sumber-sumber ekonomi yang dikuasai oleh Belanda sehingga pulau ini dikenal dengan nama "Batavia kedua". Di Pulau Dua inilah pertama kali mesjid didirikan. Setelah Belanda pergi, mereka juga pindah ke Desa Kahyapu dan memindahkan mesjid dari Pulau Dua ke Desa Kahyapu. Rata-rata masyarakat desa Kahyapu adalah orang-orang Banten yang menetap di Enggano.

Meskipun agama sudah masuk ke Enggano dan semua masyarakat Enggano adalah pemeluk agama, mereka masih melakukan beberapa tradisi yang berkaitan dengan nenek moyang mereka, salah satunya tradisi sebelum perayaan hari besar atau pernikahan. Satu hari sebelum lebaran/natal/ menikah orang-orang Enggano menyiapkan sajian berupa makanan khas seperti ikan bakar. Mereka meminta izin kepada nenek leluhur, mohon keselamatan karena kami besok mau menikah. Selain itu ada pula tradisi tahunan yang dilakukan setiap 18 Agustus dengan tujuan keselamatan dan kedamaian masyarakat dan supaya tidak ada hama (sedekah bumi kepada leluhur). Akan tetapi kegiatan ini kemudian tetap dilaksanakan dengan menarik wisatawan datang ke Enggano. Pada tanggal 18 
Agustus ini juga diadakan festival budaya di mana semua permainan tradisional Enggano ditampilkan.

Tabel 2 Jumlah Pemeluk Agama dan Tempat Ibadah di Enggano

\begin{tabular}{ccccccc}
\hline No & Desa & Islam & Kristen & $\begin{array}{c}\text { Jumlah } \\
\text { Mesjid }\end{array}$ & $\begin{array}{c}\text { Jumlah } \\
\text { Mushola }\end{array}$ & Jumlah Gereja \\
\hline $\mathbf{1}$ & Kahyapu & 535 & 8 & 2 & 2 & 1 \\
\hline $\mathbf{2}$ & Kaana & 657 & 8 & 3 & - & - \\
\hline $\mathbf{3}$ & Malakoni & 790 & 59 & 2 & 1 & 1 \\
\hline $\mathbf{4}$ & Meok & 106 & 173 & 1 & - & 1 \\
\hline $\mathbf{5}$ & Apoho & 154 & 498 & 1 & - & 3 \\
\hline $\mathbf{6}$ & Banjarsari & 645 & 83 & 2 & 5 & 2 \\
\hline & Total & 2887 & 840 & 11 & 8 & 8 \\
\hline
\end{tabular}

Sebelum masuknya agama, kegiatan ini dilakukan untuk menghormati para leluhur tetapi sekarang dilakukan makan bersama semua masyarakat Enggano. Makanan-makanan ini digantung (ikan asap, ubi, pisang, kelapa). Di masa sekarang, kegiatan ini dilakukan untuk menunjukkan kepada generasi muda bagaimana cara leluhur kita berkomunikasi kepada leluhur terdahulu. Ini merupakan bentuk terima kasih leluhur kepada pendahulunya (karena pada waktu itu mereka belum beragama dan belum mengetahui harus berterima kasih kepada siapa).

\section{Kerukunan Etnis dan Agama di Enggano}

Suku Kaamay adalah suku yang menempel pada suku asli Enggano. Keberadaan mereka diakui dan diberikan akses yang sama dengan penduduk asli, seperti tanah sebanyak 2 hektar per Kepala Keluarga (KK) yang akan didapatkan ketika berpindah kependudukan menjadi warga Enggano (Sari, 2018). Ini adalah salah satu daya tarik yang dimiliki Enggano di mata pendatang terutama bagi orangorang yang mencari sumber penghidupan baru. Mereka juga mendapatkan hak suara yang sama ketika memilih ketua suku mereka dan posisi ketua suku Kaamay setara dengan kelima kepala suku lainnya. Mereka juga dilibatkan ketika ada acara adat seperti pesta pernikahan, kematian, atau pesta pengangkatan kepala suku baru. Suku Kaamay akan diajak bersama-sama mencari ikan untuk keperluan pesta adat dan juga bersama-sama membantu mensukseskan acara tersebut.

Suku Kaamay terdiri dari campuran beberapa etnis dari seluruh Indonesia. Mayoritas mereka beretnis Jawa, Sunda, dan Bugis tetapi ada juga etnis Batak, Manado, Melayu, dan Minang. Meskipun terdapat pemisahan tempat tinggal antara penduduk asli dan pendatang tetapi pemisahan tempat tinggal tersebut tidaklah dilakukan dengan sengaja. Dahulu sebelum adanya pelabuhan Feri di Desa Kahyapu, akses keluar masuk Enggano berada di pelabuhan Perintis, di Desa Malakoni. Pada waktu itu jumlah pendatang belum terlalu banyak sehingga pusat pemerintahan dan ekonomi berada di Desa Apoho, yang dekat dengan pelabuhan Perintis. Semakin hari jumlah pendatang semakin banyak sehingga para pendatang ini ditempatkan di wilayah yang masih sepi seperti Desa Kahyapu, Kaana, Malakoni, dan Banjarsari.

Seperti yang diceritakan sebelumnya, pendatang yang masuk ke Enggano sebagian besar beragama Islam. Oleh karena itu empat desa di Enggano merupakan pemukiman mayoritas umat muslim. Seperti di Desa Kaana yang semua penduduknya beragama Islam. Di desa ini terdapat makam Datuk Sidin, orang Banten yang diyakini pertama kali membawa agama Islam di Enggano. Di wilayah ini pula lah Datuk Sidin menyebarkan agama Islam di Enggano kemudian dibantu oleh ulama-ulama yang datang setelahnya seperti ulama-ulama dari Minangkabau. Keluarga Datuk Sidin dan anak cucunya sampai saat ini menetap di Desa Kaana.

Agama adalah nilai baru yang datang ke Enggano pada awal abad ke-19 yang dibawa oleh pendatang. Sebelum datangnya agama, masyarakat Enggano meyakini bahwa arwah nenek moyang 
mereka masih tetap hidup dan menjaga keturunan-keturunan mereka. Sebelum datangnya agama mereka masih memberikan persembahan berupa makanan bagi roh nenek-moyang mereka dan tradisi tersebut sudah jarang ditemukan karena kuatnya pengaruh agama di Enggano. Tradisi menghormati nenek moyang masih tetap dilaksanakan setiap tahun pada tanggal 18 Agustus setiap tahunnya, tradisi ini juga sebagai cara masyarakat Enggano untuk menarik turis datang ke wilayah mereka untuk menikmati acara adat tahunan.

Masyarakat Enggano yang beragama Islam hidup rukun dan saling tolong-menolong dengan saudaranya yang beragama Kristen. Mereka saling mengundang dan menghadiri undangan keagamaan salah satu pihak. Sebagai contoh, ketika ada acara buka puasa bersama, pastor dan pendeta di Enggano diundang untuk ikut berbuka bersama. Para pastor dan pendeta hadir dan ikut meramaikan acara buka puasa yang dilaksanakan oleh saudaranya yang muslim. Begitu pula apabila ada pembangunan rumah ibadah seperti gereja, semua orang membantu tanpa memandang agamanya apa. Masyarakat Muslim Enggano dengan senang hati membantu pembuatan/perbaikan gereja meskipun rumah ibadah tersebut bukanlah milik mereka.

Begitu pula untuk urusan perkawinan. Masyarakat asli Enggano tidak akan melarang keturunannya untuk menikah dengan suku Kaamay. Mereka bebas memilih menikah dengan siapa saja bahkan akibat pernikahan ini ada banyak masyarakat asli Enggano yang berpindah agama mengikuti keyakinan suku Kaamay. Perpindahan agama biasanya akan menjadi pemicu konflik dalam suatu masyarakat (Lukito, 2008) tetapi tidak untuk masyarakat Enggano. Adat Enggano memberikan kebebasan yang luas bagi masyarakatnya untuk memeluk agama yang mereka yakini. Ini dikarenakan tidak ada aturan dalam adat bahwa masyarakat asli Enggano haruslah beragama Kristen. Meskipun tidak ditentang secara adat, pernikahan ini secara tidak langsung ditentang oleh pemuka agama mereka. Mereka akan melakukan pendekatan persuasif kepada calon pengantin untuk tidak meninggalkan agama mereka dan mengajak calon pasangannya untuk mengikuti agama yang dia anut. Akan tetapi lebih banyak penduduk asli Enggano yang berpindah agama menjadi Islam karena para pendatang cenderung tidak ingin mengubah identitas keagamaan mereka.

\section{Kearifan Lokal Menjaga Kerukunan}

Kunci dari harmoni dalam keragaman pada masyarakat Enggano adalah memegang teguh adat istiadat Enggano. Ketua-ketua adat bersama-sama dengan tokoh agama dan masyarakat sepakat menyelesaikan semua permasalahan secara kekeluargaan dan aturan adat yang berlaku. Seperti contoh pada tahun 2018 terdapat gonjang-ganjing dalam masyarakat karena ada beberapa keluarga yang mendirikan LDII di Enggano. Kelompok ini mengeksklusifkan diri dan tidak mau bergabung dengan masyarakat. Mereka membuat plang sendiri di rumah salah satu warga yang merupakan pendatang. Kelompok ini menurut penuturan salah satu informan mengajarkan ajaran-ajaran yang tidak sesuai dengan ajaran Islam yang biasa dilakukan oleh masyarakat Enggano sehingga terjadi kisruh. Tokoh agama, tokoh adat, dan tokoh masyarakat berembuk dan akhirnya membubarkan kelompok tersebut.

Jika ada permasalahan yang menyangkut kasus kriminal biasanya melibatkan keenam kepala suku untuk diselesaikan secara kekeluargaan. Pihak-pihak bersengketa akan dipanggil dan diajak berdiskusi secara kekeluargaan. Kepala-kepala suku akan melakukan pendekatan personal dengan pihak-pihak yang terkait mengingat mereka semua masih terikat dengan identitas persaudaraan atau identitas keagamaan. Selain itu pihak yang melakukan pelanggaran akan dikenakan sanksi adat yang tidak terlalu berat. Misalnya saja mereka harus membayar denda sebanyak Rp 50.000, parang, dan baju tetapi hal tersebut tergantung pada aturan-aturan adat yang berlaku. Kasus-kasus yang terjadi di Enggano hampir tidak pernah diselesaikan oleh pihak berwajib kecuali kasus-kasus berat seperti kasus pemerkosaan.

Masyarakat Enggano merupakan masyarakat yang sangat terbuka terutama kepada nilai-nilai baru. Mereka dengan mudah menerima kehadiran pendatang dan juga identitas keagamaan mereka. Akan tetapi hanya dua hal itulah yang bisa ditoleransi karena para pendatang harus melepaskan identitas kultural mereka ketika memasuki Enggano. Tidak ada upacara pernikahan ala Jawa, tidak ada arisan keluarga Bugis, dan sebagainya. Semuanya menyatu menjadi suku Kaamay yang diketuai 
oleh tokoh masyarakat yang berasal dari suku Kaamay yang dipilih oleh orang-orang Kaamay juga. Meskipun begitu mereka mendapat jaminan keamanan dan kesamaan hak dengan masyarakat asli Enggano.

\section{Kesimpulan}

Perbedaan identitas etnis dan agama seringkali menjadi pemicu terjadinya konflik dalam masyarakat mengingat tingginya keragaman di Indonesia. Akan tetapi masyarakat Enggano mampu menunjukkan bahwa meskipun terdapat perbedaan agama dan etnis tetapi mereka mampu hidup rukun dan damai. Hal ini dikarenakan masyarakat asli Enggano memiliki kearifan lokal yang menjaga harmoni dalam kehidupan masyarakat. Pertama, para pendatang diharuskan melepaskan identitas kultural mereka dan menggantinya dengan identitas Enggano. Dengan demikian hanya ada lima suku asli dan satu suku pendatang (Kaamay) yang diakui dan semua hak dan kewajibannya sama dengan penduduk asli. Kedua, agama adalah nilai-nilai baru dalam masyarakat Enggano sehingga adat memberikan kebebasan kepada masyarakat untuk memeluk agama dan keyakinan masing-masing bahkan berpindah agama bukanlah hal yang mengejutkan. Ketiga, para tokoh adat serta tokoh agama berhasil memberikan contoh kepada masyarakat bahwa perbedaan agama dan etnis mampu diselesaikan dengan rasa empati, tolong-menolong, dan kekeluargaan yang tinggi.

\section{Referensi}

Abdullah. (2018). Wajah Toleransi dan Perdamaian dalam Konstestasi Historitas Islam. Religious : Jurnal Studi Agama-Agama Dan Lintas Budaya, 2(2), 107-126.

Akbar, F. (2005). Marak, Simbol Agama untuk Kampanye. Tempo.Co.

Alhamid, I. (2014). Jayapura dalam Transformasi Agama dan Budaya Memahami Akar Konflik Kristen-Islam di Papua. Universitas Gadjah Mada.

Ardiansyah, S. I. (2010). Konflik Etnis Samawa dengan Etnis Bali: Tinjauan Sosial Politik dan Upaya Resolusi Konflik. Masyarakat, Kebudayaan Dan Politik, 23(4), 286-292.

Ayubi, S. Al. (2016). Cina Benteng : Pembauran dalam Masyarakat Majemuk di Banten. Kalam, 10(2), 317-358.

Chadwick, R. (2017). Embodied methodologies: challenges, reflections and strategies. Qualitative Research, 17(1), 54-74.

Dandirwalu, R., \& Rehy, H. Y. (2020). Tahuri: Symbol of the Christian-Muslim Community Peace in Tehoru and Telutih, Central Maluku, Indonesia. Wawasan: Jurnal Ilmiah Agama Dan Sosial Budaya, 5(1), 67-76.

Ekorusyono. (2015). Mengenal Budaya Enggano. Buku Litera.

Ernas, S. (2015). Politik simbol dan harmoni sosial: Makna satu tungku tiga batu dalam dinamika politik lokal di Fakfak, Papua Barat. Dialektika, 9(2), 1-18.

Ernas, S., Nugoro, H., \& Qodir, Z. (2014). Agama dan Budaya dalam Integrasi Sosial (Belajar dari Masyarakat Fakfak di Propinsi Papua Barat). Harmoni, 13(1), 22-35.

Feriyanto, F. (2018). Nilai-Nilai Perdamaian Pada Masyarakat Multikultural. Hanifiya: Jurnal Studi Agama-Agama, $1(1), 20-28$.

Hamid, I. Al. (2013). Islam Politik di Papua: Resistensi Dan Tantangan Membangun. Millah, 12(2), 441-459.

Hidayat, N. (2017). Nilai-nilai Ajaran Islam Tentang Perdamaian ( Kajian antara Teori dan Praktek ). Aplikasia: Jurnal Aplikasi Ilmu-Ilmu Agama, 17(1), 15-24.

Hutapea, \& Simangunsong, P. M. (1994). Sejarah Perkembangan Injil di Pulau Enggano. Departemen Agama Provinsi Bengkulu.

Irawan, D. (2014). Islam dan Peace Building. Religi: Jurnal Studi Agama-Agama, 10(2), 158-171.

Jaspan, M. . A. . (2018). A Note on Enggano A (Vol. 64, Issue May). Royal Anthropological Institute of Great Britain and Ireland Stable.

Lestari, D. T. (2020). Merawat Harmoni Agama melalui Kolaborasi Musik Hadroh dan Trompet di Ambon. Religious: Jurnal Studi Agama-Agama Dan Lintas Budaya, 4(3), 215-226.

Lestari, D. T., \& Parihala, Y. (2020). Merawat Damai Antar Umat Beragama Melalui Memori Kolektif dan Identitas Kultural Masyarakat Maluku. Hanifiya: Jurnal Studi Agama-Agama. https://doi.org/10.15575/hanifiya.v3i1.8697

Lindawaty, D. S. (2011). Konflik Ambon : Kajian Terhadap Beberapa Akar Permasalahan dan Solusinya. Politica, 2(2), 271-298.

Lukito, R. (2008). Hukum Sakral dan Hukum Sekuler: Studi Tentang Konflik dan Resolusi dalam Sistem Hukum 
Indonesia. Pustaka Alvabet.

Nurdin, A. (2013). Revitalisasi Kearifan Lokal Di Aceh: Peran Budaya dalam Menyelesaikan Konflik Masyarakat. Analisis, 13(1), 135-154.

Rachmadi, R. (2006). Simbol Agama Jadi Alat Intimidasi Pemilihan Kepala Daerah. Tempo.Co.

Rozi, S. (2016). Merentas jalan panjang perdamaian: Negara \& Masyarakat Dalam Resolusi Konflik. Jurnal Penelitian Politik, 3(1), 77-89.

Sari, I. P. (2017). Harmoni dalam Kebhinekaan (Kearifan Lokal Masyarakat Pulau Enggano Provinsi Bengkulu Dalam Mengatasi Konflik). Jurnal Antropologi: Isu-Isu Sosial Budaya, 19(2), 139. https://doi.org/10.25077/jaisb.v19.n2.p139-147.2017

Sari, I. P. (2018). Kerukunan Dan Toleransi Umat Beragama: Rekayasa Kearifan Lokal Dalam Manajemen Konflik Di Pulau Terluar Enggano. Zigie Utama.

van Manen, M. (2017). Phenomenology and Meaning Attribution. Indo-Pacific Journal of Phenomenology, 17(1), 112. https://doi.org/10.1080/20797222.2017.1368253

(C) 2020 by the authors. Submitted for possible open access publication under the terms and conditions of the Creative Commons Attribution (CC BY SA) license (https://creativecommons.org/licenses/by-sa/3.0/). 
Halaman ini sengaja dikosongkan 